\title{
Selección y archivo desde una aproximación crítica a la relación entre imágenes y violencia
}

Juan Manuel Díaz Leguizamon

Pontificia Universidad Javeriana, Colombia

Carlos Mario Fisgativa Sabogal

Universidad del Quindío, Colombia 


\title{
Selección y archivo desde una aproximación crítica a la relación entre imágenes y violencia*
}

Resumen: con este artículo se contribuye al debate actual sobre las estrategias para mostrar la violencia mediante el análisis del fotolibro de publicación reciente titulado La última noche, situado en el contexto del conflicto armado colombiano de la segunda mitad del siglo XX. Dado que en esta discusión cobra una relevancia inusitada la cuestión de la memoria, partimos de la aproximación de Jacques Derrida quien, apoyado en Nietzsche, nos convoca a ahondar en la relación entre archivo y memoria, y en el papel que cumplen en ella las imágenes. Según él: a) la memoria está signada por el principio de ruina, de contaminación, de intempestividad y de espectralidad; y b) el archivo no es inocente, ni se guía por la pretendida objetividad del desinterés estético, pues supone el recorte y la exclusión, e implica tensiones incesantes y procesos interpretativos que apelan a mecanismos de imposición de una autoridad. Desde ahí, buscamos reconstruir las condiciones de un diálogo productivo con otras perspectivas teóricas, como la de Walter Benjamin en la vía de interpretación propuesta por George Didi-Huberman, con el propósito de enriquecer nuestra lectura del documento citado.

Palabras clave: imágenes, archivo, memoria, montaje, violencia.

\section{Selection and archive from a critical approach to the relation between images and violence}

\begin{abstract}
: this paper adds to the current debate about the strategies to show violence through the analysis of "The Last Night", photobook recently published, and that is located in the context of the Colombian armed conflict of the second half of the XXth century. Since the topic of the memory becomes remarkably important for this discussion, we start from Jacques Derrida's approach. This author, supported by Nietzsche, summons us to elaborate further on the relationship between archive and memory, examining the role of images thereof. According to him: a) memory is signed by the principle of ruin, of pollution, of untimeliness and of spectrality; b) the archive is not innocent, nor is it guided by the alleged objectivity of aesthetic disinterest, since it involves trimming and excluding, and implies relentless tensions and interpretative processes that appeal to the imposition mechanisms of an authority. From there we proceed to rebuild the conditions of a productive dialogue with other theoretical perspectives, as that of Walter Benjamin in the way of the interpretation suggested by George Didi-Huberman, with the purpose of enriching our comprehension of the quoted document.
\end{abstract}

Keywords: images, archive, memory, montage, violence.

Fecha de recepción: 1 de junio de 2019

Fecha de aceptación: 17 de julio de 2019

Forma de citar (APA): Díaz-Leguizamon, J. M. y Fisgativa, C. M. (2020). Selección y archivo desde una aproximación crítica a la relación entre imágenes y violencia. Revista Filosofía UIS, 19(1), DOI: 10.18273/revfil. v19n1-2020013

Forma de citar (Harvard): Díaz-Leguizamon, J. M. y Fisgativa, C. M. (2020). Selección y archivo desde una aproximación crítica a la relación entre imágenes y violencia. Revista Filosofía UIS, 19(1), 247-261.

Juan Manuel Leguizamon Díaz: colombiano. Magíster en Filosofía. Profesor de la Pontificia Universidad Javeriana, Colombia.

ORCID iD: orcid.org/0000-0002-8192-9190

Correo electrónico: j.diazl@javeriana.edu.co; j.diazl.filosofia@gmail.com

Carlos Mario Fisgativa Sabogal: colombiano. Magíster en Filosofía. Profesor de la Universidad del Quindío, Colombia.

ORCID iD: orcid.org/0000-0001-5213-8675

Correo electrónico: cmfisgativa@uniquindio.edu.co; carlosmfisgativa@hotmail.com

*Artículo de reflexión derivado de investigación. 


\section{Selección y archivo desde una aproximación crítica a la relación entre imágenes y violencia}

\section{La no-inocencia de la memoria y la constitución del archivo}

La memoria, el archivo y la historia aparecen a primera vista como formas constructivas y de producción. Sin embargo, sería un error pensarlos de forma meramente positiva pues, examinados más a fondo, revelan no ser ajenos a ciertos procesos negativos y destructivos, de olvido, borradura y reescritura. Ambas situaciones se dan juntas en la perspectiva que exploramos. Este modo de abordar la inscripción de la temporalidad en la memoria humana, fijándola, ha sido ya formulado por Friedrich Nietzsche, quien desarrolla la idea de una presencia de lo intempestivo en la historia, lo cual implica que esta se encuentre habitada por una tensión latente entre diversas temporalidades. La historia y la memoria, como depositarias de un recuerdo elaborado, son lugares donde se agitan fuerzas en choque. Tal idea remite también a la forma en la que otro filósofo e historiador del arte, George Didi-Huberman, aborda la cuestión de las violentas tensiones que se agitan en y a través de las imágenes.

Según este filósofo e historiador del arte, son muchas las ocasiones en las que las fuerzas sublevan, en las que la destrucción y las pérdidas llevan a alterar el decurso histórico y sus huellas, no solo en los libros y en las imágenes, sino incluso en los cuerpos. Esto se explica porque el duelo que nos moviliza se transforma, al verse involucrado en una cadena de acontecimientos y deviene, entonces, una pasión de actuar en contra. Entonces, ante la pregunta por aquello que nos subleva, hay que que contestar que "son fuerzas, evidentemente. Unas fuerzas que no nos resultan exteriores ni impuestas: fuerzas involucionadas en todo lo que nos concierne más esencialmente" (Didi-Huberman, 2017, p. 83). Son estas las ocasiones en las que el pensamiento se eleva hasta el enojo "provocado por toda la violencia que hay en el mundo, esa violencia a la que nos negamos a estar condenados [...] hasta [...] la tarea de denunciar esa violencia con toda la calma y la inteligencia que sean posibles" (Didi-Huberman citado en Farocki, 2014, p. 14).

Desmitificando la visión ilustrada, que concibe la memoria como una actividad ante todo mental e intelectual, luminosa, serena, consciente e inocente, Nietzsche desenmascara el hecho de que se trata de una práctica que tiene un 
alto contenido material y pasional, que se dirige a los cuerpos, y que moviliza sentimientos y sensaciones extremas. Para él resulta imprescindible revelar la profunda violencia del trabajo de la memoria, la crueldad que rodea la experiencia de fijar un recuerdo:

«¿Cómo hacerle una memoria al animal-hombre? ¿Cómo imprimir algo en este entendimiento del instante, entendimiento en parte obtuso, en parte aturdido, en esta viviente capacidad de olvido, de tal manera que permanezca presente?»... Puede imaginarse que este antiquísimo problema no fue resuelto precisamente con respuestas y medios delicados; tal vez no haya, en la entera prehistoria del hombre, nada más terrible y siniestro que su mnemotécnica. «Para que algo permanezca en la memoria se lo graba a fuego; sólo lo que no cesa de doler permanece en la memoria» [...] Cuando el hombre consideró necesario hacerse una memoria, tal cosa no se realizó jamás sin sangre, martirios, sacrificios; los sacrificios y empeños más espantosos [...], las mutilaciones más repugnantes [...], las más crueles formas rituales de todos los cultos religiosos [...] —todo esto tiene su origen en aquel instinto que supo adivinar en el dolor el más poderoso medio auxiliar de la mnemónica (Nietzsche, 2009, pp. 79-80).

Ahora bien, si Nietzsche insiste en la manera como la memoria se implanta en los cuerpos individuales, Derrida se plantea más abiertamente la pregunta por la institucionalización colectiva de la misma, contenida en esa especie de forma social que constituye la base material de la memoria y de la historia, aquello que llamamos "archivo".

La decisión sobre aquello que se archiva y por ende se recuerda, y aquello que se borra y en consecuencia se olvida, está signadas por la marca de recortes, que implican violencia en la medida en que generan exclusiones y asociaciones. Y no basta con intentar explicitar sus criterios, tratando de simular coherencia, pues también están expuestos a la imposición de un deseo o de una voluntad arbitraria, o al menos descuidada. Puesto que, simultáneamente, en la memoria y en el archivado no todo cae en el orden de la decisión o del cálculo del sujeto, puesto que en su contingencia, cada decisión o recorte supone consecuencias inesperadas, indecidibles ${ }^{1}$.

\footnotetext{
"No afirmamos que habría una manera de rememorar "verdadera" o "pura", pero sí que hay usos de la memoria que buscan encubrir su proceder o que se desentienden de la importancia de problematizarlo. De lo que se trata es de asumir un ejercicio que tome como parte del mismo la crítica a los procedimientos de la construcción de la memoria y de lo que esta representa en contextos sociales concretos, pues la institución y la materialidad del archivo ofrecen resistencias, y no suelen obedecer sumisamente a la voluntad de quienes se sirven de ellos. En vez de afirmar de forma maniquea una memoria ajena a esas violencias, asumimos esas condiciones y la responsabilidad de tales decisiones y recortes, de denunciar el mecanismo y lo que produce, al igual que las consecuencias de servirnos de él parar producir otros efectos, lecturas o imágenes. No podemos obviar que muchas veces se parte de la decisión de actuar con violencia directa; pero también existen modos violentos del archivado más bien derivados o latentes, que no surgen de una voluntad asumida intencionalmente, sino que son frutos de una inercia impersonal y ciega, de los procedimientos mismos del archivado. Pretendemos considerar todos estos aspectos en nuestro examen.
} 
Efectivamente, Derrida comienza su libro Mal de archivo escudriñando el contenido histórico-etimológico de la palabra "archivo", que proviene del griego arkhé. El concepto de archivo abriga, entonces, la memoria del nombre arkhé (Derrida, 1997, p. 10), que condensa a la vez el comienzo y el mandato. Pero Derrida va más lejos cuando sostiene que "el sentido de 'archivo', su sólo sentido, le viene del arkheion griego" (p. 10), que es la residencia de los arcontes, los dignatarios que mandaban y que ejercían su influencia a partir del reconocimiento público del poder político.

Los arcontes son figuras que hacen las veces de un guardián físico del archivo, como custodios del lugar material de la memoria y de sus componentes. Y en tanto "tienen el poder de interpretar los archivos" (Derrida, 1997, p. 10), encarnan la ley, tienen la jurisdicción de decir la ley. En Grecia se institucionaliza así un sistema de derecho que debe su coherencia y su autoridad —de él y de sus representantesa ese hecho fundacional del archivo, el cual produce una versión de la identidad de la colectividad que establece entonces unos límites infranqueables (Derrida, 1997, p. 12), y que en adelante será simultáneamente el registro de la siempre violenta autofundación.

Es en este punto que Derrida reconoce que existe una "política del archivo", que "determina lo político como res publica" (Derrida, 1997, p. 12). Por eso afirma que todo poder político pasa por un control del archivo y de la memoria, y que la manera en que lo hace garantiza o impide una "democratización efectiva" (p. 12). En últimas, lo que está en juego aquí es la idea de la institución de lo común, o en términos de Rancière (2009, p. 9), los procedimientos por los cuales se parten, reparten y comparten las condiciones de la experiencia. Todos estos se constituyen en elementos que configuran un escenario para el debate acerca de las memorias, las imágenes y los archivos de los conflictos y las violencias. Y este encuentra eco no solamente en los teóricos "occidentales", sino que también siembra un acontecer muy próximo a la necesidad que tenemos en Latinoamérica de replantear nuestras identidades, obligados a pensar con y a través de las imágenes y los archivos, antes que nada, problematizándolos (Díaz, 2018). Máxime cuando la constitución de nuestro archivo imaginario, aquel que está llamado a servir de insumo para nuestras identidades, ha estado altamente atravesado por una relación histórica conflictiva, si es que no abiertamente violenta, con una serie de "otros", con los cuales tendremos que seguir negociando formas, ojalá más constructivas, de mutuo reconocimiento. Esto si partimos de la idea de que el fenómeno concreto de la identidad latinoamericana arrastra consigo y demuestra con mayor claridad un problema de un alcance más general, el de la identidad de toda cultura en tanto es relacional: "la inevitabilidad de llegar a imágenes de uno mismo a través de los ojos del otro, y el beneficio que se extrae de ello en cuanto a la calidad y potencia de dichas imágenes" (Díaz, 2018, p. 151). 
Para decir algo concretamente de Colombia, lugar al cual nos remitiremos enseguida, cabe citar la posición de Juan Felipe Urueña precisamente en lo que respecta a la relación del archivo visual con lo que podría ser un posicionamiento democráticamente efectivo frente a una historia de violencia, desde sus aspectos políticos:

En el caso de las políticas de la memoria en Colombia, es inevitable pensar en las posibilidades que un adecuado uso del archivo visual puede otorgar para tener diferentes puntos de entrada a los sucesos violentos del pasado, en especial si se tiene en cuenta el variado y abundante archivo del que se dispone, y que está conformado por imágenes de múltiples contextos de producción: imágenes artísticas, pinturas, caricaturas, películas; imágenes informativas, tanto documentales como "sensacionalistas"; imágenes de espectáculo, publicitarias, de entretenimiento, etc. (Urueña, 2017, p. 102).

\section{Sobre el mal de archivo, el derecho de mirada y la selección}

Según se viene mostrando, el archivo siempre ejerce un corte e impone una fuerza: "es una violenta iniciativa de autoridad, de poder, es una toma de poder para el futuro, pre-ocupa el futuro; confisca el pasado, el presente y el futuro. Ya sabemos que no existen archivos inocentes" (Derrida, 2013, p. 349). También se advirtió que, por más que suponga la selección, el corte y la exclusión, el archivo también escapa a la pura intencionalidad. Para señalar este hecho se plantea, tanto en Mal de Archivo (1997) como en "El cine y sus fantasmas" (2013), el principio de ruina en el archivo: la contaminación, la subversión del documento, su carácter intempestivo y espectral. Pero también se extienden estos planteamientos a los nuevos medios.

Al tratar acerca del cine, Derrida evidencia que la captura, proyección y reproducción de las imágenes suponen la alteración de temporalidades que no se guían por un movimiento progresivo. Asimismo, no deja de notar que en los procesos de encuadre y en la selección de material y escenas para el montaje, se llevan a cabo elecciones que producen recortes violentos, en cuanto separan y excluyen de lo archivable. Precisamente en eso consiste para él la violencia de la ley, la condición para la consignación. No obstante, sin esos recortes no serían posibles ni la memoria ni el encadenamiento de elementos discretos propios de lo audiovisual. Estos planteamientos tienen su análogo en las consideraciones de Didi-Huberman sobre las imágenes, cuando sostiene que estas nunca se dan ajenas a la manipulación (Didi-Huberman citado en Farocki, 2014, pp. 14-15), pero que lo importante es saber cómo están montadas y cómo nos tocan:

[...] no existe una sola imagen que no implique, simultáneamente, miradas, gestos y pensamientos. Dependiendo de la situación, las miradas pueden ser ciegas o penetrantes; los gestos, brutales o delicados; los pensamientos, inadecuados o sublimes. [...] no existe tal cosa como una imagen que sea 


\begin{abstract}
pura visión, absoluto pensamiento o simple manipulación. Es especialmente absurdo intentar descalificar algunas imágenes bajo el argumento de que aparentemente han sido "manipuladas". Todas las imágenes del mundo son el resultado de una manipulación, de un esfuerzo voluntario en el que interviene la mano del hombre (incluso cuando esta sea un artefacto mecánico). Solo los teólogos sueñan con imágenes que no hayan sido producidas por la mano del hombre -las imágenes aquiropoyetas de la tradición bizantina, las ymagine denudari de Meister Eckhart (DidiHuberman citado en Farocki, 2013, pp. 14-15).
\end{abstract}

Desconfiar de las imágenes no solo es el título de una recopilación de textos de Harun Farocki, sino una consigna que resume una tendencia de apreciación de la imagen, en la que coinciden Farocki, Didi-Huberman y Derrida:

Existe, en nuestra idea occidental de la creencia, una desconfianza irreductible hacia la imagen en general y la imagen filmada en particular. Esto puede interpretarse como una forma de arcaísmo, la idea de que la percepción, el verbo o el escrito en su presencia real son los únicos que tienen derecho, que son creíbles (Derrida, 2013, p. 338).

Efectivamente, nuestra perspectiva parte del carácter siempre modificado, interpretado o formateado de las imágenes y de los archivos, ya que esta es una condición de su producción, recepción y conservación. Es por ello que las decisiones técnicas de enfoque, de movimiento, de lugar y de tiempo, de discurso, de archivo o de descarte determinan aquello que es visible y legible, lo que es puesto en escena y ofrecido a los espectadores. Igualmente, los criterios para el archivado, así como lo relativo al acceso, son problemas relevantes, ya que siempre acarrean "la decisión, la responsabilidad, la respuesta, y por consiguiente la selección crítica, la elección [...] siempre hay elección, sea o no consciente" (Derrida y Stiegler, 1998, p. 189). Los nuevos medios y soportes implican así problemas inéditos, ante los cuales hay que generar debates. Sería irresponsable simplemente someterse a las condiciones emergentes que surgen a partir de su implementación, de ahí la necesidad de interrogarse cuestiones como: ¿quiénes archivan, eligen, seleccionan y montan el material?, ¿cuáles son los criterios para ello?, ¿es posible o no acceder al material transmitido en la radio, en la televisión o en internet?, ¿cómo se construye y se usa la memoria?, ¿cómo contar la historia de las culturas contemporáneas?

Al inicio de Ecografías de la televisión se alude al "derecho de mirada", el cual remite a la fuerza que se ejerce al separar y reunir en una selección, montaje o archivo, pero también a la obligación que imponen las imágenes de no detener el ejercicio crítico, la reinterpretación y la producción de nuevas lecturas y escrituras respecto a ellas. De modo que el "derecho de mirada" también tiene que ver con el lenguaje, con el discurso que acompaña a las imágenes y dirige la interpretación. Esto es mencionado también en el texto Droit de regards que sigue al catálogo 
fotográfico del mismo nombre: "en la foto-novela el discurso hace la ley, dicta el derecho, su jurisdicción se extiende al derecho de mirada. Tiene el derecho de mirada sobre las imágenes al imponerles a ustedes una sola interpretación" (Plissart y Derrida, 1985, pp. VII-VIII) ${ }^{2}$. Tratando de evitar ese problema, o al menos para dejarlo bien señalado, en este catálogo se prescinde del pie de las fotos, de las referencias o leyendas que identifiquen las imágenes o expliquen su secuencia, por lo cual, según Joaná Masó, se suspende "la autoridad del discurso sobre la imagen fotográfica" (Masó, 2011, p. 362).

Encontramos aquí otro rasgo que remite a lo señalado por Nietzsche respecto a la activa capacidad del olvido y su fuerza plástica, indispensable para la memoria, pero por lo mismo sujeta a la influencia de la trasformación de sus múltiples variables (Nietzsche, 2009, pp. 75-76). Esto resuena con esta afirmación derridiana: "la memoria entraña el olvido. Si hay selectividad, es porque hay olvido (Derrida y Stiegler, 1998, p. 85). De hecho, la noción derrideana de escritura y la noción de imagen suponen la inscripción, la borradura y la repetición. Efectivamente, estos son rasgos del pensamiento de la huella, que a su vez retoma interrogantes abordados por otros pensadores como Freud, Nietzsche y Emmanuel Levinas (cfr. Derrida, 2005, p. 91). En particular, y dada la utilidad para nuestro argumento, destacamos el ejemplo tomado del psicoanálisis, en el que Freud se sirve de metáforas sobre la escritura para explicar el funcionamiento del psiquismo.

Después de muchos rodeos y de intentar otras explicaciones del funcionamiento del psiquismo, llegó Freud a servirse de la metáfora del block o tablero mágico que le sirve para explicar la economía del inconsciente. El Wunderblock consiste en una película de escritura en cuya superficie no se marcan huellas que se borran aparentemente al remover la película del block, pero según señala Freud (1992, pp. 243-247), esas huellas se conservan como borradas o tachadas; análogamente, así funcionaria el aparato psíquico que no solo almacena intuiciones o representaciones, sino que graban e inscribe huellas heterogéneas e irreductibles a la presencia o a la conciencia (Freud, 1993, p. 188). Estas huellas mnémicas permanecen sin ser traducibles o visibles, pero dan testimonio de las impresiones recibidas y de la forma en que su magnitud es diferida para proteger la película misma de la inscripción violenta que podría desgarrarla (Derrida, 1989, p. 307).

Apoyándose en el mecanismo del Wunderblock, para Derrida la marca es marca y la huella es huella en tanto que cada una se borra y con ello borra la posibilidad de la presencia. La huella repite la imposibilidad de una presencia plena e inmediata, la imposibilidad de su intuición, traducción, percepción o aprensión.

Traducción propia. 


\section{Selección y archivo desde una aproximación crítica a la relación entre imágenes y violencia}

Así mismo, el inconsciente como escritura cuestiona la remisión originaria a un presente como fundamento de escritura, ya que la escritura del inconsciente es huella, marca y a la vez borradura (al levantar la hoja de celuloide). Esto permite hablar del inconsciente como superficie y máquina de escritura, de huellas que se remarcan dejando la traza de la inscripción violenta, pero a su vez se borran, pues no obedecen a una presencia plena sino a un desplazamiento.

Llevando esto a nuestra indagación, tenemos que las imágenes, al igual que toda forma de memoria, suponen el olvido, debido a que, en tanto huellas o marcas, solo son posibles porque están expuestas a ser repetidas, borradas y superpuestas con otras escrituras, como ocurre con el palimpsesto. Efectivamente, tanto en la reiteración como en la inscripción, necesariamente se altera lo rememorado.

Sin embargo, no consideramos que estas aproximaciones a la memoria y al archivo se reduzcan a ejercicios de olvido cómplice o a la irresponsable renuncia a contar o recordar lo ocurrido. Por el contrario, y apoyándonos en las consideraciones de Derrida, Nietzsche y Didi-Huberman, nuestro abordaje supone el intento de figurar, montar, exponer imágenes y relatos ante las situaciones atroces que nos convocan con urgencia; sin dejar de asumir la violencia de las decisiones, selecciones y recortes que efectuamos. Por ello, y anunciando lo que nos ocupará en el apartado final de este texto, remitimos al artículo "Los fantasmas no inquietan nunca a las cosas muertas", de María Victoria Uribe, quien al hablar del conflicto colombiano señala:

La Violencia ha sido olvidada por la mayoría de los colombianos que desconocen sus causas y poco indagan por sus consecuencias. Sus contenidos atroces no fueron socializados y su simbolización ha sido muy precaria. Fuera de los sobrevivientes y de los investigadores que la han estudiado, ¿quién en Colombia reconoce ese pasado vergonzante y en ruinas como algo propio? (Uribe, 2018, p. 98).

Tenemos hasta aquí elementos que nos permiten extender el debate acerca de la memoria, las imágenes y el archivo en relación con la violencia ${ }^{3}$, para

\footnotetext{
${ }^{3}$ Como se nota en la cita anterior, involucramos en nuestro análisis nuevos tipos de violencia. Partimos en la primera parte de considerar el tipo de violencia que Žižek ha llamado "objetiva", en sus dos modalidades: "simbólica", en relación a las arbitrariedades, exclusiones e imposiciones al nivel de nuestros aparatos cognitivos y de generación de sentido (en nuestro caso, en la manera como se ha entendido el oficio y la operación de comprender el pasado, constituir memoria y mantenerla) y "sistémica", la del funcionamiento injusto de sistemas y modelos político-económicos que funcionan de manera estructural. Y pasamos ahora a integrar al análisis violencias de tipo "subjetivo", aquellas que se pueden atribuir a agentes específicos e individuales. Resulta importante subrayar que las dos modalidades de violencia objetiva son mucho más difíciles de constatar, son invisibles y mediatas, mientras que la subjetiva es más directamente visible, y aparece a la inmediatez de la experiencia (Žižek, 2018, pp. 9-10).
} 
considerar ahora manifestaciones artísticas recientes en Latinoamérica y, en particular, relativas al conflicto colombiano ${ }^{4}$.

\section{Montajes de palabras o de fotografía}

Elevar el propio pensamiento hasta el nivel del enojo, elevar el propio enojo hasta el nivel de una obra. Tejer esta obra que consiste en cuestionar la tecnología, la historia y la ley. Para que nos permita abrir los ojos a la violencia del mundo que aparece inscrita en las imágenes (Didi-Huberman citado en Farocki, 2014, p. 35).

En esta parte final, remitimos a un libro de fotografías recientemente publicado por Juan José Horta Soto (2018): La última noche. Más que tratar de explicar, descifrar o resolver lo que estaría en juego "detrás" o "en el fondo" de esas imágenes, hemos querido reencauzar hacia un medio nuevo, el de los conceptos, el cuestionamiento que ellas hacen de la visibilidad. Desde la perspectiva que acabamos de presentar, en la que, si bien no hay coincidencia entre el lenguaje y la imagen, en la línea de Walter Benjamin y de Didi-Huberman, tampoco hay pura disidencia entre ellos, ni menos aún un silencio que tengamos el deber de resguardar, ni que sea necesariamente cómplice (Fisgativa, 2016). En la perspectiva derridiana que también asumimos nos preguntamos entonces iqué mirar y cómo mirarlo?, ¿qué decir y cómo decirlo?, ¿cómo volver a mostrar eso que miramos, para con ello inquietar? Queremos reivindicar y ejercer nuestro derecho a mirar, y también nuestro derecho a decir algo acerca de eso que miramos, tanto en este libro como en nuestra realidad colombiana, buscando con ello generar algún efecto.

La última noche no incluye texto. No presenta pies de página, prólogo, ni conclusiones; tampoco índice, segmentación por partes, o una estructura distinta a la de las 17 fotografías en su mero aparecer: retratos de armas de largo alcance, utilizadas en la horrible noche de la guerra en Colombia. Si bien la riqueza de estas imágenes incita a efectuar numerosos comentarios, de entrada resulta difícil desconocer el gesto que parece conminar a un silencio contemplativo, el cual sugiere una renuncia y renuencia expresa a describir, contextualizar, comentar o explicar el material visual (esa siempre violenta ley y derecho de mirada del que nos habla Derrida, pues en su carácter doble y contradictorio [double bind], nos retira la posibilidad de control sobre las imágenes pero nos obliga a estar

\footnotetext{
${ }^{4}$ Nos resulta necesario remitir a la clasificación o tipificación de las violencias propuestas por Johan Galtung a partir de sus investigaciones, intervenciones y mediaciones en diferentes conflictos. Galtung (2016) señala que la violencia no se puede reducir a sus aspectos más visibles como son la agresión bélica, física o el secuestro, sino que la violencia directa tiene como correlato la violencia estructural (enraizada en los sistemas sociales y sus instituciones), al igual que la violencia cultural que legitima o tiende a naturalizar los otros tipos de violencia y se asienta en las prácticas y discursos cotidianos, así como en los símbolos.
} 
vigilantes, nos retira el discurso coherente sobre las imágenes, pero nos interpela exigiendo nuestras palabras).

También se evidencia una especie de confianza depositada en la potencia de las imágenes, como un dar por sentado que estas tienen una dinámica propia que las abre a posibilidades diversas: significantes, emocionales, expresivas o informativas. En todo caso, al presentarlas, se dispone con ellas su capacidad de convertirse en trozos formativos que pueden contribuir a (re)construir la memoria de un pasado y a proponer los esbozos de un futuro. Al espectador le corresponde también la frágil confianza depositada en las potencias de la imagen, pues es dejado libre para percibir e interpretar, ya que no son muchas las indicaciones externas. Solo dos aspectos intervienen en este proceso: el título que signa la obra y un par de cartas testimoniales que son reproducidas en un formato familiar: el de los cuadernos usados en la escuela. Se trata de cartas que contienen tanto rastros autobiográficos como rastros de guerra y promesas de paz.

Así, las cartas y las fotografías nos ofrecen fragmentos, huellas a partir de las cuales se insinúan y provocan relatos, a la vez que se evocan memorias. Esto a pesar tanto del silencio que es propio de las imágenes e intrínseco a ellas, como del ruido ensordecedor y aturdidor de aquellos artefactos bélicos que han sido retratados. Efectivamente, esta ambigüedad se hace manifiesta en el título que oscila entre la esperanza sin garantías depositada en un deseado silenciamiento de las armas, y la anhelada certeza de una sentencia locuaz que, a viva voz, pueda declarar el fin del conflicto: gritar con el pecho henchido de júbilo que esta fue "la última noche". Pero, si recordamos el gesto genealógico legado por Nietzsche, no solo habría que preguntarse por el "qué" de aquella sentencia, sino también por el "quién" de esa última noche. Por eso, sostenemos que esta obra activa una mirada crítica pues, a la vez que despliega numerosos cuestionamientos acerca de la historia reciente del país, también lo hace acerca de las condiciones de la figurabilidad, de la representación y del carácter de monumento de cualquier documento.

Algunas consideraciones extras han de hacerse en particular, respecto a una de las imágenes del fotolibro, una que, entre todas, resulta especial. Es aquella que se arma por el anverso de las otras fotos totalmente desplegadas, las cuales se encuentran dispuestas de tal modo que, al juntarse a la manera de un friso, se reúnen como piezas de una gran imagen compuesta. En ella se observa la impronta dejada por un arma que ya no está, su silueta sobre una sábana blanca arrugada. La gran imagen producida por el conjunto de estas fotografías al desplegarse y girarse, no es sintética ni conclusiva. En contraste con el aparecer positivo de las armas sobre las camas, se obtiene ahora esta imagen ofrecida por los pliegues de la tela blanca, una especie de no-imagen que encarna el indicio de una presencia que ya no se preserva, emanando del espacio dejado por un objeto pesado que desordena el textil, y que parece el epítome de un problema que ha torturado 
siempre a la teoría de la imagen, pues introduce dimensiones éticas y políticas en lo que de otro modo sería una cuestión puramente estética o una estetización de lo político, en el sentido benjaminiano.

Este problema no es otro que la pregunta, en contextos de atrocidades, acerca de si es posible y necesario representar la violencia. Y es que, al tratar de hacerlo, se corre el riesgo de caer con facilidad en ejercicios desafortunados: revivir el dolor y multiplicar la injusticia causada por la violencia; revictimizar al volver a exponer mecánicamente y sin mediaciones aquello que se creía superado, o incluso encumbrándolo; estetizar aquello que se rechaza, justificándolo, embelleciéndolo o haciéndolo digerible, o banalizar y normalizar los hechos, mediante una repetición desensibilizadora. Al respecto señala Urueña:

Las imágenes de los hechos violentos dan cuenta de una situación paradójica.
Dejan en evidencia [...] los límites de la representación [...] dan muestra de
la imposibilidad de hacer sentido sobre aquello que fuerza los márgenes de
lo decible o mostrable. Sin embargo, su inapelable existencia exige buscar
modos de hacer sentido con ellas y de tratar de comprender los contextos
en los que han sido producidas. Estas imágenes expresan al mismo tiempo
la crisis de la representación y la exigencia de representar lo que parece
irrepresentable. Ignorarlas es tan reprochable como reproducirlas. Al ser las
imágenes vehículos de información cada vez más presentes en el contexto
de información de las sociedades contemporáneas, es fundamental someter
a reflexión crítica la forma paradójica en la que tiende a presentarse la
discusión entre el todo y la nada; entre el silencio reverencial y el fetiche
del ídolo; entre el olvido indiferente y el recuerdo mercantilizado; entre
las imágenes banales y las palabras sagradas. En este contexto se considera,
tomando prestada la expresión de Didi-Huberman, que la cuestión debe
ser analizada desde los límites imprecisos del pese a todo (2004), el cual
obliga a pensar las dicotomías irreconciliables como polaridades dinámicas.
En ese intersticio es posible pensar al mismo tiempo los límites del lenguaje
y [...] las formas expresivas y sus posibilidades pese a todo. Es en ese frágil
intersticio en donde el método del montaje puede ser ubicado (Urueña,
2017, pp. 100-101).

Consideramos que el recurso a esa no-imagen final hace que la obra tome una vía casi mística, en el buen sentido ${ }^{5}$, con el que se logra resolver la paradoja sin renunciar a representar, pero tampoco representando solo explícitamente. Dicho recurso nos remite al modo en que, según cuenta Didi-Huberman, Farocki se pregunta cómo denunciar los excesos de la violencia sin hacer cerrar los ojos

\footnotetext{
Entendemos por esto una posición que logra una visión de la realidad que se eleva por encima de la obviedad y la inmediatez propias de lo material en su apariencia más básica. La actitud que se desprende de ella es la comprensión de la interdependencia de todo con todo, la cual da paso a un respeto por la vida, a una valoración del ser y a un sentido de la solidaridad y de la compasión. Comprendemos como una vía mística en sentido negativo aquella que daría paso a una actitud de distancia y retirada de los asuntos "mundanos", la cual termina alimentando en el fondo un sentido de falsa superioridad e indiferencia que puede tornarse incluso en crueldad.
} 
o el pensamiento de los espectadores, planteando una alternativa como la que se expone en El fuego inextinguible (Didi-Huberman, 2017, p. 10). Nos lleva, siguiendo la terminología propuesta por Urueña, a encontrar una vía intermedia, prometedora, aunque frágil (el pese a todo de Didi-Huberman), que abre un espacio entre lo irrepresentable y lo hiperrepresentable, sitúandose más bien en el cómo representar; abre una grieta entre la negación de ver y el deseo voyerista, para encontrarse más bien con la pregunta sobre cómo ver con distancia crítica (Urueña, 2017, pp. 101-102).

Si seguimos ahondando en esta imagen, encontramos otro aspecto sumamente relevante que tiene que ver con el motivo de la sábana, la cual no se limita a dar acogida a una ausencia, sino que registra fuerzas en tensión, asuntos enmarcados en una importante tradición que incluye, entre otros, a Walter Benjamin (1989, 2008, 2010), Aby Warburg (2013), y Didi-Huberman (1997, 2008, 2005). Y esto nos lleva a prolongar la indagación. En los pliegues de las telas o drapeados se manifiestan las tensiones contradictorias de fuerzas invisibles, cuyas dinámicas agitan las imágenes por las fuerzas en movimiento que operan sobre ellas. Al respecto escribe Didi-Huberman:

Un sudario blanco inmóvil puesto encima de un cuerpo, pero que de repente se agita, se levanta, se convierte en vestido de novia o en bandera izada en lo alto de un mástil antes de desgarrarse alegremente, he aquí algo que manifiesta en las superficies -o en lo que Aby Warburg llamaba "accesorios en movimiento", refiriéndose a lo que ha atravesado la historia de las artes como uno de los más antiguos "formantes" estéticos, me refiero al drapeado- la fuerza de las sublevaciones (Didi-Huberman, 2017, p. 87).

Una sábana, una mortaja, los vestidos de las ménades danzantes, la cobija del habitante de la calle, como resto de la sociedad capitalista o las frazadas de las fotografías en cuestión, son todas estas superficies que se desgarran, que resisten y se sublevan. Incluso en un tejido terso se encuentran las fuertes tensiones que la toma de una imagen ofrece: desde el cálido abrigo de una última noche, hasta los resplandores de otro tiempo. El susurro de un adiós o los ecos de lamentos incesantes, aunque de intensidad siempre cambiante. Ecos y destellos ralentizados por el lente fotográfico que tiene en su objetivo otros artefactos, ante los cuales también se ve expuesto y frágil, como un espejo. Cualquier palabra sería a la vez excesiva e insuficiente. No es que el silencio sea necesario, es que el ruido no ha sabido aún cesar y no ha de interferir con las voces que quisieran aclamar alguna historia.

En suma, las imágenes de este fotolibro muestran que la construcción del pasado y de sus interpretaciones futuras solo puede surgir tras una decisión compositiva: del montaje de fragmentos y del cruce de series de hechos y situaciones teóricamente inagotables. Un montaje que en términos benjaminianos es dialéctico, en tanto que aproxima y hace colisionar valores extraños entre sí, 
poco familiares solo en apariencia. A su vez, esto permite actuar, "denunciar: elevar el propio pensamiento hasta el nivel del enojo. Protestar. Separar, voltear las cosas que parecen caer de suyo. Pero también establecer, en un nivel, una relación entre cosas que, en otro nivel, parecen completamente antagónicas" (Didi-Huberman citado en Farocki, 2013, p. 33). De modo que, lo que hace el montaje es un procedimiento crítico que altera el orden de las cosas, de las preguntas de los discursos y de las imágenes, creando relaciones entre elementos y temporalidades antagónicas que constituyen a su vez una crítica de la violencia. En este sentido, el montaje compensa la violencia de sus inevitables recortes, ocultamientos y exclusiones, al abrazar la positividad de una producción afirmativa que se hace cargo, no solo de lo que hace aparecer, sino de lo que negativamente termina dejando de lado, en las sombras de lo invisible.

\section{Referencias}

Benjamin, W. (1989). Tesis de filosofía de la historia. En Discursos interrumpidos I. Filosofía del arte y de la historia (pp. 175-191). Buenos Aires: Taurus.

Benjamin, W. (2008). La obra de arte en la época de su reproductibilidad técnica. En Obras, libro I/Vol. II. Madrid: Abada.

Benjamin, W. (2010). El origen del Trauerspiel alemán. En Obras, libro I/Vol. I. Madrid: Abada.

Derrida, J. (1989). La escritura y la diferencia. (P. Peñalver, trad.). Barcelona: Anthropos.

Derrida, J. (1997). Mal de Archivo. Una impresión freudiana. Madrid: Trotta.

Derrida, J. (2005). De la gramatología. (O. Del Barco y C. Cerreti, trads.). Ciudad de México: Siglo XXI Editores.

Derrida, J. (2013). Artes de lo visible (1979-2004). (J. Masó y J. Bassas, trads.). Castellón: El Lago Ediciones.

Derrida, J. y Stiegler, B. (1998). Ecografías de la Televisión. Entrevistas Filmadas. Buenos Aires: Eudeba.

Díaz, J. M. (2018). Teoría mimética y América latina: el vigente problema de la identidad, un diálogo que nos convoca. Cuadernos de Filosofía Latinoamericana, 39(118), 143-158. DOI: https://doi.org/10.15332/25005375 
Didi-Huberman, G. (1997). Lo que vemos, lo que nos mira. (H. Pons, trad.). Buenos Aires: Manantial.

Didi-Huberman, G. (2005). La venus rajada. Madrid: Losada.

Didi-Huberman, G. (2008). La emoción no dice 'yo'. Diez fragmentos sobre la libertad estética. En Alfredo Jaar. La política de las imágenes. Santiago de Chile: Metales pesados.

Didi-Huberman, G. (2017). Sublevaciones. Buenos Aires: Untref.

Farocki, H. (2014). Desconfiar de las imágenes. Buenos Aires: Caja Negra.

Fisgativa, C. (2016). Lenguaje y alegoría. Modos de considerar el arte a partir de Walter Benjamin. Revista de filosofía UIS, 15(2), 137-155.

Freud, S. (1992). El yo y el ello y otras obras (1923-1925). En Obras completas, Tomo XIX. Buenos aires: Amorrortu.

Freud, S. (1993). Los textos fundamentales del psicoanálisis. Barcelona: Altaya.

Galtung, J. (2016). La violencia: cultural, estructural y directa. Cuadernos de estrategia, 183, 147-168.

Horta, J. (2018). La última noche. Bogotá: publicación independiente.

Nietzsche, F. (2009). La genealogía de la moral. Madrid: Alianza Editorial.

Masó, J. (2011). Illustrer, photographier, le point de suspension ou l'image chez Jacques Derrida. En J. Adnen (ed.), Derrida et la question de I'art, déconstructions de l'esthétique (pp. 361-383). Nantes: Éditions Cécile Defaut.

Plissart, M. F. y Derrida, J. (1985). Droit de regards. Paris: Minuit.

Rancière, J. (2009). El reparto de lo sensible. Estética y política. Santiago de Chile: LOM Ediciones.

Uribe, M. V. (2018). Los fantasmas no inquietan nunca a las cosas muertas: Entre el Terror y el desaliento en Colombia. Revista M, 3(5), 92-102.

Urueña, J. F. (2017). El montaje en Aby Warburg y en Walter Benjamin: un método alternativo para la representación de la violencia. Bogotá: Universidad del Rosario. 
Warburg, A. (2013). La primavera de Boticelli. Madrid: Casimiro.

Žižek, S. (2018). Sobre la violencia. Barcelona: Paidós. 